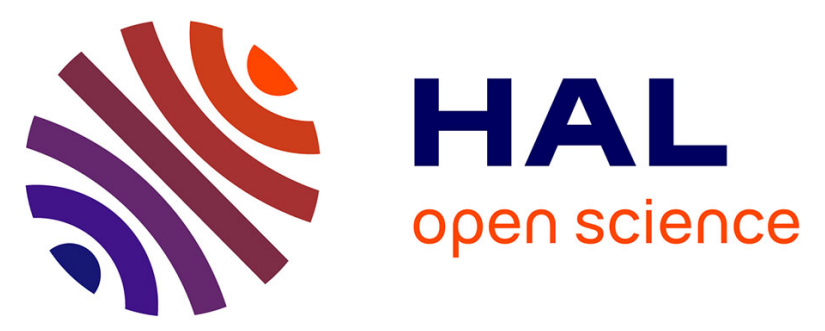

\title{
Halogen bonding-based anion coordination in calixarene/inorganic halide/diiodoperfluorocarbon assemblies
}

Serena Biella, Giuseppe Gattuso, Anna Notti, Pierangelo Metrangolo, Sebastiano Pappalardo, Melchiorre F. Parisi, Tullio Pilati, Giuseppe Resnati, Giancarlo Terraneo

\section{To cite this version:}

Serena Biella, Giuseppe Gattuso, Anna Notti, Pierangelo Metrangolo, Sebastiano Pappalardo, et al. Halogen bonding-based anion coordination in calixarene/inorganic halide/diiodoperfluorocarbon assemblies. Supramolecular Chemistry, 2009, 21 (01-02), pp.149-156. 10.1080/10610270802516955 . hal-00513544

\section{HAL Id: hal-00513544 \\ https://hal.science/hal-00513544}

Submitted on 1 Sep 2010

HAL is a multi-disciplinary open access archive for the deposit and dissemination of scientific research documents, whether they are published or not. The documents may come from teaching and research institutions in France or abroad, or from public or private research centers.
L'archive ouverte pluridisciplinaire HAL, est destinée au dépôt et à la diffusion de documents scientifiques de niveau recherche, publiés ou non, émanant des établissements d'enseignement et de recherche français ou étrangers, des laboratoires publics ou privés. 


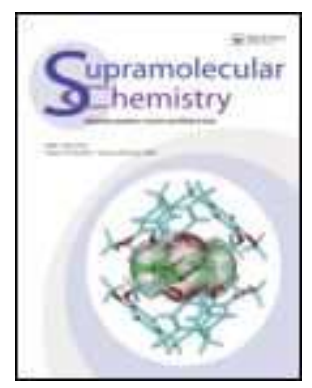

\section{Halogen bonding-based anion coordination in calixarene/inorganic halide/diiodoperfluorocarbon assemblies}

\begin{tabular}{|r|l|}
\hline Journal: & Supramolecular Chemistry \\
\hline Manuscript ID: & GSCH-2008-0111.R1 \\
\hline Manuscript Type: & Full Paper \\
\hline Date Submitted by the & $18-$ Sep-2008 \\
\hline Complete List of Authors: & $\begin{array}{l}\text { Biella, Serena; Politecnico di Milano } \\
\text { Gattuso, Giuseppe; Università di Messina } \\
\text { Notti, Anna; Università di Messina } \\
\text { Metrangolo, Pierangelo; Politecnico di Milano } \\
\text { Pappalardo, Sebastiano; Università di Catania } \\
\text { Parisi, Melchiorre; Università di Messina, Dipartimento di Chimica } \\
\text { Organica e Biologica } \\
\text { Pilati, Tullio; ISTM-CNR } \\
\text { Resnati, Giuseppe; Polytechnic of Milan } \\
\text { Terraneo, Giancarlo; Politecnico di Milano }\end{array}$ \\
\hline \hline Keywords: & $\begin{array}{l}\text { Anion coordination, Calixarenes, Comb-like copolymer, Halogen } \\
\text { bonding, X-ray }\end{array}$ \\
\hline
\end{tabular}

\section{ScholarONE \\ Manuscript Central}




\section{Halogen bonding-based anion coordination in calixarene/inorganic halide/diiodoperfluorocarbon assemblies}

Serena Biella, ${ }^{a}$ Giuseppe Gattuso, ${ }^{\text {b }}$ Anna Notti, ${ }^{\text {b }}$ Pierangelo Metrangolo, ${ }^{\mathrm{a}}$ Sebastiano Pappalardo, ${ }^{\mathrm{c}}$ Melchiorre F. Parisi, ${ }^{\mathrm{b}}$ Tullio Pilati, ${ }^{\mathrm{d}}$ Giuseppe Resnati $^{* \mathrm{a}}$ and Giancarlo Terraneo ${ }^{\mathrm{a}}$

aNFM-Lab DIMIC "G. Natta" Politecnico di Milano, via Mancinelli 7, 20131, Milano, Italy; 'bipartimento di Chimica Organica e Biologica, Università di Messina, salita Sperone 31, 98166 Messina, Italy; ${ }^{\mathrm{C} D i p a r t i m e n t o ~ d i ~}$ Scienze Chimiche, Università di Catania, Viale A. Doria 6, 95125 Catania, Italy; ${ }^{\mathrm{d}}$ ISTM-CNR Università degli Studi di Milano, via Venezian 21, 20133 Milano, Italy

Self-assembly of ternary mixtures composed of cation segregating agent/inorganic halide (pentatert-butylpentakis(ethoxycarbonylmethoxy)calix[5]arene (1)/NaI or 4,7,13,16,21,24-hexaoxa-1,10diazabicyclo[8,8,8]hexacosane $\left.(4) / \mathrm{BaI}_{2}\right)$ and diiodoperfluorocarbon (1,8-diiodoperfluorooctane (2)) produces crystalline supramolecular salts 3 and 5, respectively, whose structural characteristics in the solid state have been elucidated by single-crystal $X$-ray analyses. Encapsulation of alkali or alkali-earth metal ions inside the complexing pocket of the appropriate receptor generates naked iodide anions, which effectively drive the self-assembly of | diiodoperfluorooctane 2 into halogen-bonded supramolecular anions with a comb-like copolymer structure.

Keywords: Anion coordination; Calixarenes; Comb-like copolymer; Halogen bonding; X-ray

\section{INTRODUCTION}

Cation coordination chemistry has contributed to major advances in and benefited by major contributions from several areas of chemistry spanning both fundamental studies (e.g. aggregation, recognition, and self-assembly processes) and application-oriented investigations (e.g. phase transfer catalysis, waste-water cleaning, light emitting devices) [1]. The toolbox of modules to design and implement cation coordination is quite rich and allows for specific strategies tailored to fit the substrate cation and the targeted function.

Anion coordination is a much less developed area [2]. While moderately good information is available on the construction of discrete adducts through endo recognition of anions [3], the understanding of exo recognition phenomena involving anions is still in its infancy [4], and a tremendous difference exists between the ability to self-assemble infinite networks by using cations as compared to anions as templating agents.

Halogen bonding (XB) is a non-covalent interaction in which halogens act as electron acceptors (Lewis acids, XB donors) [5]. For a given halogen site, the higher the electron density on the electron donor partner (Lewis base, XB acceptor), the stronger the resulting XB [6]. Anions (e.g. iodides and bromides) usually give rise to stronger XBs than neutral electron donors [4h] (e.g. the nitrogen atoms of amine and pyridine moieties or the oxygen atoms of ether and carbonyl functionalities) and it has already been reported that both discrete adducts and infinite networks can be formed when polydentate $\mathrm{XB}$ donors are used [7]. Interestingly, with a given $\mathrm{XB}$ donor (e.g. 1,8-diiodoperfluorooctane and 1,2diiodotetrafluoroethane) iodide ions can work as mono-, bi-, or tridentate XB acceptors and as a result trimeric adducts [8], 1D [4 $4 \mathrm{~b}, 4 \mathrm{i}, 9], 2 \mathrm{D}$ [4a $4 \mathrm{c}, 7 \mathrm{a}, 10]$, or $3 \mathrm{D}[4 \mathrm{c}, 7 \mathrm{a}, 11]$ networks can be formed.

Halides are spherical anions and the nature of the associated cation affects their coordination valency when involved in XB formation. The size and shape of the cation influence its distance from the anion and consequently the tendency of the anion to work as electron donor (namely its coordination number and sphere) [12]. Moreover, cation size and shape also influence the geometry and the metrics of the crystal packing and thus affect the size and shape of the space potentially available for the supramolecular anion. Indeed, we have shown how the topology of the overall crystal packing can be designed in detail when the mutual fit between cation and anion is conveniently controlled $[4 \mathrm{a}, 8 \mathrm{a}, 9 \mathrm{a}]$ ].

Two classes of selective cation sequestering agents will be presented in this paper, the calix[5] arene 1 and the cryptand K.2.2.2 4. Their ability to tightly accommodate alkali and alkali-earth metal ions of different sizes is well known [13], but the fate of the counterion freed upon complexation has scarcely been investigated. We will report here on the formation of the hybrid supermolecule 3 obtained from calixarene/ $\mathrm{NaI} /$ diiodoperfluorooctane ternary mixtures and on its structural properties in the solid state. The structural features of the supramolecular anion formed upon anion-templated assembly of diiodoperfluorooctane $\mathbf{2}$ will be described and compared with the supramolecular anion present in the hybrid supermolecule $\mathbf{5}$, where the anion and the diiodoperfluorocarbon modules are the same but the metal cation and its sequestering agent are different ( $\mathrm{Ba}^{2+}$ and K.2.2.2, respectively).

\begin{tabular}{l} 
Deleted: $4 \mathrm{i}$ \\
Deleted: $4 \mathrm{e}$ \\
Deleted: $4 \mathrm{f}$ \\
Deleted: $4 \mathrm{~g}$ \\
Deleted: $7 \mathrm{~b}$ \\
Deleted: $4 \mathrm{~g}$ \\
\hline
\end{tabular}

Deleted: 11
Deleted: 4
Deleted: 8
Deleted: 9




\section{RESULTS AND DISCUSSION}

\section{1 \\ Penta-tert-butyl- pentakis(ethoxycarbonylmethoxy)calix[5]arene/N aI/1,8-diiodoperfluorooctane assembly}

The self-assembly of ternary adducts compounded of calixarenes, perfluorocarbons, and inorganic salts was carried out by using penta-tert-butylpentakis(ethoxycarbonylmethoxy)calix[5]arene (1) [14], NaI, and 1,8-diiodoperfluorooctane (2). Diiodooctane $\mathbf{2}$ has already been proven to act as an efficient XB donor towards iodide anions [15]. Calixarene 1, on the other hand, is known to be an effective ionophore [14] and a selective carrier of sodium cations through liquid membranes [16]. The use of $\mathbf{1}$ was then expected to provide, upon sodium iodide exposure, "naked" iodide anions readily available for XB formation.

The $\left[\mathrm{Na}^{+} \subset \mathbf{1}\right] \mathrm{I}^{-}$complex was obtained as a white powder upon evaporation of a methanol solution of equimolar amounts of $\mathbf{1}$ and NaI. The formation of the supramolecular cation $\left[\mathrm{Na}^{+} \subset \mathbf{1}\right]$ featuring a $\mathrm{Na}^{+}$ ion embedded in the ionophoric pocket created by the ethereal and carbonyl oxygen atoms at the lower rim of the calixarene was confirmed by ${ }^{1} \mathrm{H}$ NMR and ESI-MS spectral data [17].

$\mathrm{X}$-ray quality single crystals of the ternary system 3 were obtained by slow evaporation of an ethanolic solution of $\left[\mathrm{Na}^{+} \subset \mathbf{1}\right] \mathrm{I}^{-}$in the presence of $\mathbf{2}$ (see Experimental section for details). Variation of the $\left[\mathrm{Na}^{+} \subset \mathbf{1}\right] \mathrm{I}^{-}: \mathbf{2}$ ratio in the $1: 1$ to $1: 2$ interval had no effect on the isolation of the final adduct 3 . The stepwise assembly of $\mathbf{3}$ is illustrated in Scheme 1.

Single crystal X-ray analysis of $\mathbf{3}$ has revealed the structural details of the system. The $\left[\mathrm{Na}^{+} \subset \mathbf{1}\right] \mathrm{I}^{-}$to $\mathbf{2}$ ratio is $1: 2$ and iodide anions are involved in the formation of three XBs. This is consistent with a remarkable electron donor ability of the iodide anion, derived from a particularly effective ion pair dissociation. Calix[4]arene derivatives have already been used to sequestrate potassium, cesium and barium cations and generate naked iodide anions to be involved in halogen bonding-driven selfassembly. The adduct $\mathbf{3}$ is the first example of a supramolecular salt exploiting $\mathrm{NaI}$ as the iodide ion source and a preorganized cone calix[5]arene derivative as a segregating agent. It appears that $\left[\mathrm{Na}^{+} \subset \mathbf{1}\right] \mathrm{I}^{-}$can be considered a valuable alternative to previous XB acceptors based on calix[4]arene/alkali metal iodide adducts. The elucidation of the structure of the supercation component arising from a sodium calix[5]arene pentaester complex in the co-crystals of $\mathbf{3}$ is unprecedented in the literature.

In the solid state the complex adopts a distorted cone conformation, quite similar to the one found for the free host 1 [14] and the sodium complex of a structurally related calix[5]arene pentaketone [18]
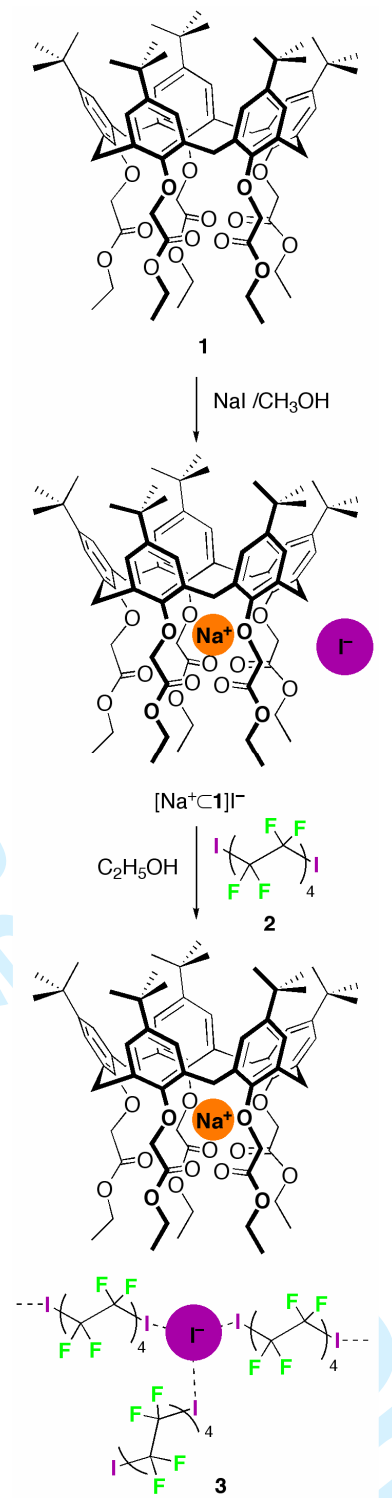

Scheme 1. Stepwise assembly of the supramolecular salt 3 (1/NaI/2, 1:1:2 ratio). 
One of the five tert-butylphenyl residues (ring E) is leaning towards the interior of the upper rim hydrophobic calixarene cavity, while the other four are pointing outwards. The tilt angles of the aromatic rings to the mean plane of the bridging methylenes

| are $136.68,107.95,102.79,137.03$, and $61.66^{\circ}$ for rings A to E, respectively. The relatively small $\mathrm{Na}^{+}$ ion is surrounded by a seven coordinated oxygen cage composed of two phenolic oxygens, four ester carbonyl oxygen atoms and a water molecule. It lies off-center from the lower rim ionophoric cage because the outward-oriented pendant group of the self-inclined ring is not involved in the complexation. The $\mathrm{Na}^{+} \cdots \mathrm{O}$ distances are in the range of 2.326 $2.918 \AA$ (Figure 1).

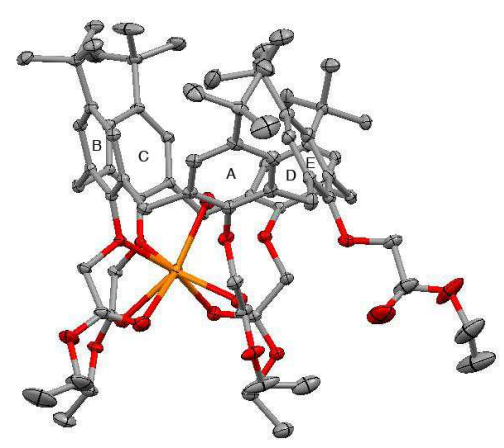

Figure 1. Side view of the supercation component $\left[\mathrm{Na}^{+} \subset \mathbf{1}\right]$ present in the co-crystal 3. ADPs at $50 \%$ probability level. Colors are as follows: carbon, gray; oxygen, red and sodium, orange. Here and in all other Figures, only one conformation of the disordered groups is drawn; hydrogen atoms are omitted for clarity.

The phenolic rings in the calixarene structure are quite rigid since they have to comply with the conformational requirements dictated by the ion complexation. By contrast, the pendants bonded to the phenolic oxygens potentially display great mobility and can assume a large variety of conformations. In the supercation $\left[\mathrm{Na}^{+} \subset \mathbf{1}\right]$ two of the ethoxycarbonylmethoxy chains are doubly bonded and two are singly bonded to the sodium. Despite the fact that data were collected at $90 \mathrm{~K}$, the pendants show some conformational disorder, one of the

I chains being refined in two conformations with population factor ratio $0.672 / 0.328$.

The supramolecular cations $\left[\mathrm{Na}^{+} \subset \mathbf{1}\right]$ loosely interact with each other in the crystal packing as they are separated by halogen bonded perfluorinated supramolecular anions having the structure of comblike copolymers (Figure 2). Iodide anions act as tridentate electron donors towards the iodine atoms of diiodoperfluorooctane $\mathbf{2}$, the latter working as either bidentate or monodentate electron acceptor(s). The bidentate diiodoperfluorooctane molecules interconnect the iodide anions, leading to the formation of unlimited chains; the monodentate diiodoperfluorooctane modules are also appended to the iodide anions, forming the teeth of the halogenbonded comb-like copolymer. The angles around the iodide anions are 78.42(2), 76.73(3) and 145.14(1) for $\mathrm{I} 3 \cdots \mathrm{I} 5 \cdots \mathrm{I} 2, \quad \mathrm{I} 3 \cdots \mathrm{I} 5 \cdots \mathrm{I} 1_{-}^{i}(i=x, 1+y, z) \quad$ and $\mathrm{I} 2 \cdots \mathrm{I} 5 \cdots \mathrm{I} 1^{i}$, respectively. The $\mathrm{XB}$ lengths are

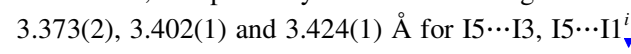
and $15 \cdots \mathrm{I} 2$, in that order. These distances are very short (in the ternary adduct $\left[\mathrm{K}^{+} \subset \mathrm{K} \cdot 2.2 .2\right]\left\{\left[\mathrm{I}-\left(\mathrm{CF}_{2}\right)_{8}{ }^{-}\right.\right.$ $\left.\mathrm{I}_{2} \mathrm{I}^{-}\right\}$where the iodide anions are tridentate, the $\mathrm{I} \cdots \Gamma$ distances are $3.474 \AA$ ) and indicate strong interactions, once again consistent with a high degree of ion pair dissociation.

In general, the difluoromethylene groups of halogen-bonded $\alpha, \omega$-diiodoperfluoroalkanes show some disorder, while the iodine atoms, pinned by the $\mathrm{XB}$, are ordered. This is also the case in the $\left[\mathrm{Na}^{+} \subset \mathbf{1}\right]\left\{\left[\mathrm{I}-\left(\mathrm{CF}_{2}\right)_{8}-\mathrm{I}\right]_{2} \mathrm{I}^{-}\right\}$supramolecular assembly $\mathbf{3}$, where most of the carbon and fluorine atoms of the monodentate diiodooctane modules, and some of the carbon and fluorine atoms of the bidentate diiodooctane modules, were split over two locations with occupancy 0.5 in order to model the disorder. Interestingly, the terminal iodines of the teeth, which are not involved in any XBs, also show some disorder.

Figure 2. The superanion $\left\{\left[\mathrm{I}-\left(\mathrm{CF}_{2}\right)_{8}-\mathrm{I}_{2} \mathrm{I}^{-}\right\}_{\text {ne }}\right.$ present in the cocrystal 3. ADPs at $50 \%$ probability level. Colors are as follows: Formatted: Subscript carbon, gray; fluorine, green and iodine, purple.

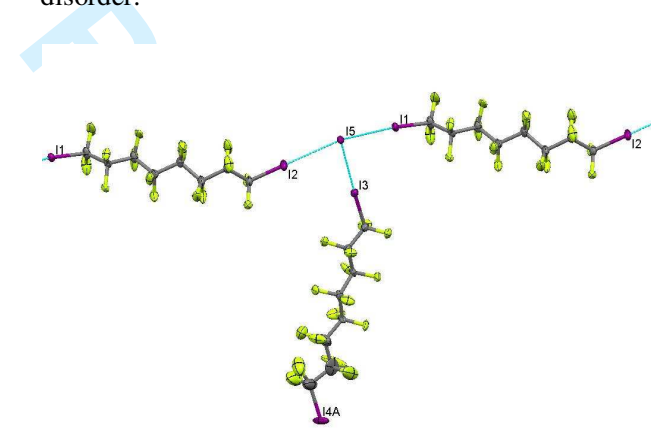

Deleted: four
Deleted: two
Deleted: $\mathrm{I}^{i}$
Deleted: $(i=x, 1+y, z)$


2.2.

$4,7,13,16,21,24-H e x a o x a-1,10$ diazabicyclo[8,8,8]hexacosane/BaI $2 / 1,8$ diiodoperfluorooctane assembly

For the purpose of comparison, adduct $\mathbf{5}$ compounded of 4,7,13,16,21,24-hexaoxa-1,10-diazabicyclo[8,8,8]hexacosane (K.2.2.2) $\quad 4, \mathrm{BaI}_{2}$, and diiodoperfluorooctane $\mathbf{2}$ was also investigated. Crystallization of a methanol solution of $\mathbf{4}$ and $\mathrm{BaI}_{2}$ afforded the solid cryptate $\left[\mathrm{Ba}^{2+} \subset 4\right] 2 \mathrm{I}^{-}$. Single crystals suitable for X-ray analysis of the threecomponent system $\left[\mathrm{Ba}^{+} \subset \mathbf{4}\right]\left\{\left[\mathrm{I}-\left(\mathrm{CF}_{2}\right)_{8}-\mathrm{I}\right]_{3} 2 \mathrm{I}^{-}\right\} \quad 5$ (Scheme 2) were isolated by evaporation of a methanol solution of $\left[\mathrm{Ba}^{+} \subset \mathbf{4}\right] 2 \mathrm{I}^{-}$in the presence of $\mathbf{2}$ (see Experimental section for details).
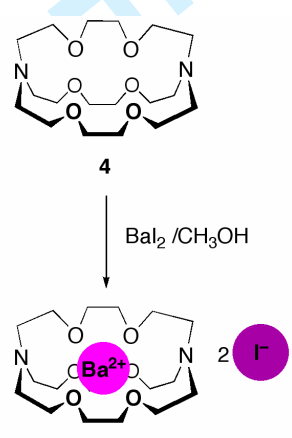

$\left[\mathrm{Ba}^{2+} \subset 4\right] 2 \mathrm{I}^{-}$
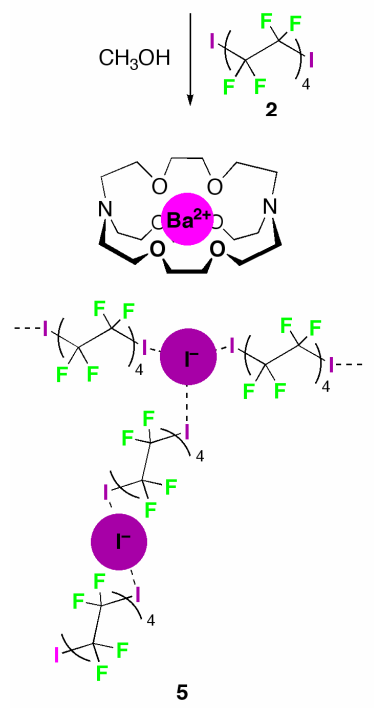

Scheme 2. Stepwise assembly of the supramolecular assembly $\mathbf{5}$ | (4/BaI $2 / 2,1: 1: 3$ ratio $)$.
$\mathrm{X}$-ray analysis shows that barium cations are, as expected, embedded in the K.2.2.2 core (Figure 3, top) and the coordination sphere is saturated by two additional molecules of methanol. The supramolecular and halogen-bonded anions are seen as comb-like copolymers structurally similar to those observed in $\mathbf{3}$, the greatest difference being the size of the teeth, which are longer in $\mathbf{5}$ than in $\mathbf{3}$ (Figure 3, bottom). Table 1 reports lengths and angles of XBs in the comb-like superanions of $\mathbf{5}$ where both diiodoperfluorooctane molecules, the $\mathrm{XB}$ donor modules, and the iodide anions, the $\mathrm{XB}$ acceptor modules, show two different binding modes.

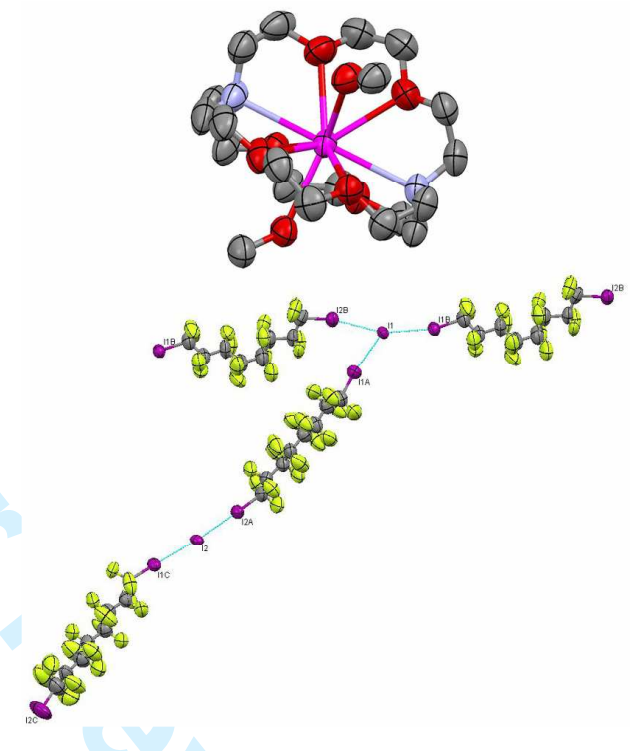

Figure 3. The supercation $\left[\mathrm{Ba}^{2+} \subset 4\right]$ and the superanion $\left\{\left[\mathrm{I}-\left(\mathrm{CF}_{2}\right)_{8}-\right.\right.$ $\left.\mathrm{I}_{3} 2 \mathrm{I}^{-}\right\}_{\mu_{2}}$ components (top and bottom, respectively) present in the

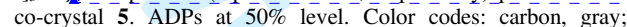
oxygen, red; barium, pink; nitrogen, light blue; fluorine, green and iodine, purple.

Table 1. XB lengths and angles of the superanion components of 5.

\begin{tabular}{cccc}
\multicolumn{2}{c}{ Distance $(\AA)$} & \multicolumn{2}{c}{ Angle $\left({ }^{\circ}\right)$} \\
\hline I1-I1A & $3.584(4)$ & I1A-I1-I1B & $126.96(13)$ \\
I1-I1B & $3.531(5)$ & I1A-I1-2B & \\
I1-I2B & & \\
& $3.603(5)$ & I1B-I1-I2B & $70.30(11)$ \\
I2-I2A $^{i i}$ & $3.464(4)$ & I2A $^{i i}-$ I2-I1C & $160.93(11)$ \\
I2-I1C & $3.442(4)$ & & \\
\hline
\end{tabular}

The iodide I1 is tridentate and forms the unlimited chains of the copolymer on binding two diiodoperfluorooctane molecules (specifically, on binding I1B and translated $\mathrm{I} 2 \mathrm{~B}(\mathrm{x}, \mathrm{y}, 1+\mathrm{z}))$. These two diiodoperfluorooctane molecules are bidentate and
Formatted: Subscript 
adopt a ttgtt [19] conformation along their carbon backbone. I1 also binds a third diiodoperfluorooctane molecule which is bidentate, adopts a distorted all trans conformation, and forms the teeth of the comblike copolymer. These teeth are further elongated through the $\mathrm{I} 2 \cdots \mathrm{I} 2 \mathrm{~A}(-1+x, y,-1+z)$ and $\mathrm{I} 2 \cdots \mathrm{I} 1 \mathrm{C}$ XBs involving the iodide anion $\mathrm{I} 2$, which is bidentate, and another diiodoperfluorooctane molecule, which is in turn monodentate. As previously seen in the case of 3, here too the terminal monodentate diiodoperfluorooctane molecule shows some degree of disorder at its end.

Fluoroalkane derivatives have a low affinity for hydrocarbon derivatives [20] and thus it is not surprising that the supramolecular fluorous anions and hydrocarbon cations are segregated from each other and give rise to adjacent layers which alternate in the crystal of the two supramolecular assemblies 3 and $\mathbf{5}$ (Figure 4).

a)

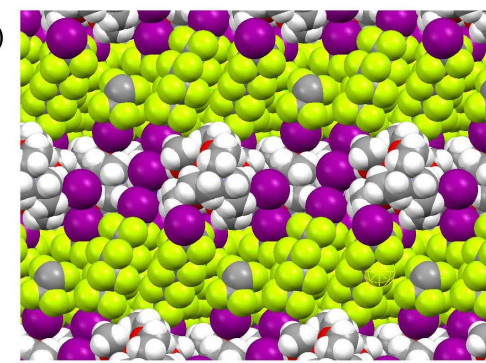

b)

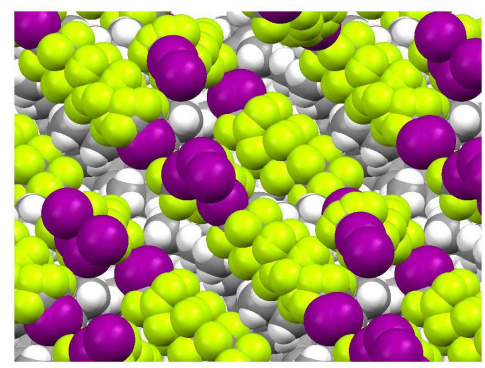

Figure 4. Space-filling representation of the different types of segregation present in the co-crystals, $\mathbf{5}$ (a) projection parallel to the hydrocarbon/perfluorocarbon layers and $\mathbf{3}$ (b) projection nearly parallel to the teeth. Colors are as follows: carbon, gray; hydrogen, white; oxygen, red; fluorine, green, and iodide, purple.

A similar behavior has already been observed in several other perfluorocarbon/hydrocarbon hybrid systems [21]. Interestingly, segregation is much less pronounced in 3 (Figure $4 \mathrm{~b}$ ), probably partly as a consequence of the lower content of fluoroalkyl groups which in turn results from the lower content of iodide ions required to counterbalance a mono- $v s$ a double-charged cation of the original salt $\left(\mathrm{Na}^{+}\right.$in $\mathbf{3} v s$ $\mathrm{Ba}^{2+}$ in 5).

\section{CONCLUSIONS}

We have demonstrated that cation segregating agents $\mathbf{1}$ and $\mathbf{4}$ generate naked iodide anions which effectively drive the self-assembly of diidoperfluorooctane $\mathbf{2}$ into halogen-bonded supramolecular anions with a comb-like structure, a hitherto unreported topology.

It had been previously reported how -on using metal cations and cation coordinating agents different from those employed here- naked iodide anions were generated which worked either as mono-, bi-, or tridentate $\mathrm{XB}$ acceptors and assembled diiodoperfluorooctane $\mathbf{2}$ into three component adducts wherein the supramolecular anion was a discrete system, an infinite chain, or a $(6,3)$-network, respectively [7-10]. The three-component adduct 5 is the first structure wherein iodide anions with different coordination numbers coexist in the same crystal. Specifically, iodide anions act as both bi- and tridentate $\mathrm{XB}$ acceptors. X-ray data show that differences in supercation size and shape $\left(\left[\mathrm{Na}^{+} \subset \mathbf{1}\right]\right.$ and $\left.\left[\mathrm{Ba}^{2+} \subset 4\right]\right)$ produce halogen-bonded comb-like copolymers with different metrics and crystal packing. $\left[\mathrm{Na}^{+} \subset \mathbf{1}\right]$ creates a dense hydrocarbon packing in $\mathbf{3}$, while in $\mathbf{5}$ the greater content of perfluoroalkane residues promotes a more pronounced segregation of the hydrocarbon and perfluorocarbon layers.

The results reported here suggest that the cation coordinating agent plays two interrelated roles in allowing metal iodides to assemble iodoperfluorocarbons into supramolecular anions with complex topologies. The primary role is to form a naked iodide anion, namely to allow it to act as an $\mathrm{XB}$ acceptor. The key parameter in this case is its effectiveness in sequestrating the cation. The secondary role is to tune the induced $\mathrm{XB}$ acceptor ability of the anion and in this case the key parameter is the size and shape of the supramolecular counterion. When effectively naked, iodide anions are rather chameleonic XB acceptors [7-10]. The number and geometry of the XBs they form and the topology of the resulting supramolecular anion is heavily influenced by the restraints that the inherent packing preferences of the cation impose on the overall crystal packing. Further studies are underway to verify whether the XB acceptor ability of other naked halide anions (e.g. bromide anions) is similarly sensitive to cation nature, size, and shape. 


\section{EXPERIMENTAL}

\subsection{General Methods}

Melting points were determined on a Kofler melting point apparatus and are uncorrected. ${ }^{1} \mathrm{H}$ and ${ }^{19} \mathrm{~F}$ NMR spectra (300 and $282 \mathrm{MHz}$, respectively) were obtained at $293 \mathrm{~K}$, using TMS and $\mathrm{CFCl}_{3}$ as internal standards. FT-IR spectra were recorded as $\mathrm{KBr}$ pellets on a Nicolet Nexus FT-IR spectrophotometer equipped with the Smart Endurance system (UATR). All solvents and chemicals were reagent grade and were used without further purification. Calixarene $\mathbf{1}$ was prepared according to a reported procedure [14미]

Procedure for the formation of the hybrid supermolecular salts

1/NaI/2 (3). Solid $\left[\mathrm{Na}^{+} \subset \mathbf{1}\right] \mathrm{I}^{-}$was crystallized from a 1:1 mixture of pentaester $\mathbf{1}$ and $\mathrm{NaI}$ in methanol. Cocrystal $\mathbf{3}$ was grown in an uncapped clear borosilicate glass vial, placed inside a sealed chamber partially filled with vaseline oil, by slow evaporation at room temperature, from an absolute ethanol solution of $\left[\mathrm{Na}^{+} \subset \mathbf{1}\right] \mathrm{I}^{-}$and $\mathbf{2}$ in equimolar amounts.

4/BaI 2 /2 (5). In a similar way, co-crystals 5 were obtained by slow evaporation, at room temperature, of a methanol solution containing equimolar amounts of $\left[\mathrm{Ba}^{2+} \subset \mathbf{4}\right] 2 \mathrm{I}^{-}$and $\mathbf{2}$.

\section{Inclusion complex $\left[\mathrm{Na}^{+} \subset 1\right] \mathrm{I}^{-}$}

Mp $146-156{ }^{\circ} \mathrm{C}\left(\mathrm{CH}_{3} \mathrm{OH}\right)$; FT-IR (selected bands) $2963,2875,1747,1480,1385,1238,1191,1129$, and $1069 \mathrm{~cm}^{-1} ;{ }^{1} \mathrm{H}$ NMR $\left(\mathrm{CDCl}_{3}\right) \delta 1.04(\mathrm{~s}, 45 \mathrm{H}$, $\left.\mathrm{C}\left(\mathrm{CH}_{3}\right)_{3}\right), 1.34\left(\mathrm{t}, J=7.1 \mathrm{~Hz}, 15 \mathrm{H}, \mathrm{CH}_{2} \mathrm{CH}_{3}\right), 3.35$ and $4.36\left(\mathrm{AX}, J=13.9 \mathrm{~Hz}, 10 \mathrm{H}, \mathrm{ArCH}_{2} \mathrm{Ar}\right), 4.28$ (q, $\left.J=7.1 \mathrm{~Hz}, 10 \mathrm{H}, \mathrm{CH}_{2} \mathrm{CH}_{3}\right), 4.50\left(\mathrm{~s}, 10 \mathrm{H}, \mathrm{OCH}_{2}\right)$, and $6.96(\mathrm{~s}, 10 \mathrm{H}, \mathrm{Ar} H) \mathrm{ppm}$.

\section{Co-crystal 3}

Mp 199-200 ${ }^{\circ} \mathrm{C}\left(\mathrm{C}_{2} \mathrm{H}_{5} \mathrm{OH}\right)$; FT-IR 2964, 2907, 2871 , $1748,1481,1215,1072,633$, and $545 \mathrm{~cm}^{-1}$. The ${ }^{1} \mathrm{H}$ NMR spectrum of $\mathbf{3}$ is superimposable to that of $\left[\mathrm{Na}^{+} \subset \mathbf{1}\right] \mathrm{I}^{-} .{ }^{19} \mathrm{~F}$ NMR $\left(\mathrm{CD}_{3} \mathrm{OD}\right) \delta-123.45$ (4 F, $\left.\mathrm{CF}_{2} \mathrm{CF}_{2} \mathrm{CF}_{2} \mathrm{CF}_{2} \mathrm{I}\right),-122.68\left(4 \mathrm{~F},-\mathrm{CF}_{2} \mathrm{CF}_{2} \mathrm{CF}_{2} \mathrm{I}\right)$, $114.90\left(4 \mathrm{~F},-\mathrm{CF}_{2} \mathrm{CF}_{2} \mathrm{I}\right)$, and $-61.52\left(4 \mathrm{~F},-\mathrm{CF}_{2} \mathrm{I}\right)_{2}$ ppm.

Inclusion complex $\left[\mathrm{Ba}^{2+} \subset 4\right] 2 \mathrm{I}^{-}$

Mp 290-292 ${ }^{\circ} \mathrm{C}\left(\mathrm{CH}_{3} \mathrm{OH}\right)$; FT-IR 3510, 2886, 2844 , 2049, 1607, 1475, 1356, 1255, 1124, 952, and 928 $\mathrm{cm}^{-1} ;{ }^{1} \mathrm{H}$ NMR $\left(\mathrm{CD}_{3} \mathrm{OD}\right) \delta 2.55-2.59(\mathrm{~m}, 12 \mathrm{H}$,
$\left.\mathrm{OCH}_{2} \mathrm{CH}_{2} \mathrm{~N}\right), 3.57-3.59\left(\mathrm{~m}, 12 \mathrm{H}, \mathrm{OCH}_{2} \mathrm{CH}_{2} \mathrm{~N}\right)$, and $3.62\left(\mathrm{~s}, 12 \mathrm{H}, \mathrm{OCH}_{2} \mathrm{CH}_{2} \mathrm{O}\right) \mathrm{ppm}$.

\section{Co-crystal 5}

Mp $165-170{ }^{\circ} \mathrm{C}\left(\mathrm{CH}_{3} \mathrm{OH}\right)$; FT-IR 3453, 2886, 2831, $1629,1214,1154,1106$, and $953 \mathrm{~cm}^{-1} ;{ }^{1} \mathrm{H}$ NMR $\left(\mathrm{CD}_{3} \mathrm{OD}\right) \delta 2.56-2.60\left(\mathrm{~m}, 12 \mathrm{H}, \mathrm{OCH}_{2} \mathrm{CH}_{2} \mathrm{~N}\right), 3.55-$ $3.59\left(\mathrm{~m}, 12 \mathrm{H}, \mathrm{OCH}_{2} \mathrm{CH}_{2} \mathrm{~N}\right)$, and $3.64(\mathrm{~s}, 12 \mathrm{H}$, $\left.\mathrm{OCH}_{2} \mathrm{CH}_{2} \mathrm{O}\right) \mathrm{ppm} ;{ }^{19} \mathrm{~F}$ NMR $\left(\mathrm{CD}_{3} \mathrm{OD}\right) \delta-122.13(4$ $\left.\mathrm{F}, \mathrm{CF}_{2} \mathrm{CF}_{2} \mathrm{CF}_{2} \mathrm{CF}_{2} \mathrm{I}\right),-121.33\left(4 \mathrm{~F},-\mathrm{CF}_{2} \mathrm{CF}_{2} \mathrm{CF}_{2} \mathrm{I}\right),-$ $113.76\left(4 \mathrm{~F},-\mathrm{CF}_{2} \mathrm{CF}_{2} \mathrm{I}\right)$, and $-62.39\left(4 \mathrm{~F},-\mathrm{CF}_{2} \mathrm{I}\right)_{2}$ ppm.

\subsection{Crystal Structure Determinations}

Single-crystal_ X-ray_diffraction measurements were performed on a Bruker APEX CCD area detector diffractometer, graphite monochromator, Mo-K $\alpha$ radiation $(\lambda=0.71073 \AA)$. The structures were solved by SIR2002 [22] and refined by full-matrix leastsquares on $\mathrm{F}^{2}$, using SHELXL-97 [23]. Hydrogen atoms were introduced in calculated positions and not refined. All crystallographic data (excluding structure factors) have been deposited with the Cambridge Crystallographic Data Centre as supplementary publications nos CCDC 697160 and 237537 for $\mathbf{3}$ and 5, respectively. Copies of the data can be obtained free of charge on application to CCDC, 2 Union Road, Cambridge CB2 1EZ, UK, E-mail: deposit@ccdc.cam.ac.uk

\section{Crystal Structure of 3}

$\mathrm{C}_{91} \mathrm{H}_{102} \mathrm{~F}_{32} \mathrm{I}_{5} \mathrm{NaO}_{16}, \quad \mathrm{Mr}=2733.33$, triclinic, space group $\mathrm{P}-1, \mathrm{a}=16.555(2), \mathrm{b}=18.865(2), \mathrm{c}=21.391(2)$ $\AA, \quad \alpha=96.55(2), \quad \beta=112.05(2), \quad \gamma=113.97(2)^{\circ}$, $\mathrm{V}=5370.4(10) \AA^{3}, \mathrm{Z}=2, \rho=1.680 \mathrm{~g} \mathrm{~cm}^{-3}, \mu($ Mo- $K \alpha)=$ $1.566 \mathrm{~mm}^{-1}$. Data were collected at $\mathrm{T}=90 \mathrm{~K}$, because at room temperature the mean intensity of the reflections vanished at very low values of $2 \theta .188801$ reflections were collected up to $2 \theta=72.41 ; 49938$ unique [40459 with $\left.I_{0}<2 \sigma\left(I_{\mathrm{o}}\right)\right], R_{\mathrm{ave}}=0.0428$. Final disagreement factors for all (observed) reflections: $R w\left(F^{2}\right)=0.1580(0.1489)$ and $R=0.0841(0.0677)$, goodness-of-fit $=1.093,1528$ parameters, 529 restraints. In spite of the low temperature of data collection, both the perfluorinated molecules were partially disordered and were refined with some restraints on geometry and ADP parameters; the same was true for an ethoxycarbonyl pendant of $\mathbf{1}$. Other ethoxycarbonyl and tert-butyl pendants of $\mathbf{1}$ showed large ADPs but it was impossible to split these groups into two models because of very large correlation parameters. 


\section{Crystal Structure of 5}

$\mathrm{C}_{44} \mathrm{H}_{44} \mathrm{BaF}_{48} \mathrm{I}_{8} \mathrm{~N}_{2} \mathrm{O}_{8}, \quad \mathrm{Mr}=2793.35$, triclinic, space group $\mathrm{P}-1, \mathrm{a}=13.068(3), \mathrm{b}=17.900(4), \mathrm{c}=19.064(4)$ $\AA, \quad \alpha=109.88(2), \quad \beta=96.18(3), \quad \gamma=94.75(3)^{\circ}$, $\mathrm{V}=4135.1(18) \AA^{3}, \mathrm{Z}=2, \rho=2.243 \mathrm{~g} \mathrm{~cm}^{-3}, \mu(\mathrm{Mo}-K \alpha)=$ $3.618 \mathrm{~mm}^{-1}$, room temperature. 56251 reflections were collected up to $2 \sigma=55.10 ; 19054$ unique 11321 with $\left.I_{\mathrm{o}}<2 \sigma\left(I_{\mathrm{o}}\right)\right], R_{\mathrm{ave}}=0.0426$. Final disagreement factors for all (observed) reflections: $R w\left(F^{2}\right)=$ $0.1081(0.1015)$ and $R=0.0640(0.0371)$, goodnessof-fit $=0.946,1389$ parameters, 3978 restraints. Two of the three perfluorinated molecules were completely disordered and refined with restraints both on geometric parameters and ADPs.

\section{REFERENCES}

[1] Eryazici, I.; Moorefield, C. N.; Newkome, G. R. Chem. Rev. 2008, 108, 1834-1895; Fromm, K. M. Coord. Chem. Rev. 2008, 252, 856; Mao, J.-G. Coord. Chem. Rev. 2007, 251 1493-1520; Kruppa, M.; König, B. Chem. Rev. 2006, 106, 3520-3560; Morohashi, N.; Narumi, F.; Iki, N.; Hattori, T.; Miyano, S. Chem. Rev. 2006, 106, 5291-5316; Baleizão, C.; Garcia, H. Chem. Rev. 2006, 106, 3987-4043; Zilbermann, I; Maimon, E.; Cohen, H.; Meyerstein, D. Chem. Rev. 2005, 105, 2609-2625; Alessio, E. Chem. Rev. 2004, 104, 4203 4242; Gokel, G. W.; Matthew Leevy, W.; Weber, M. E. Chem. Rev. 2004, 104, 2723-2750; Lane, B. S.; Burgess, K. Chem. Rev. 2003, 103, 2457-2473; Gorden, A. E. V.; Xu, J.; Raymond, K. N. Chem. Rev. 2003, 103, 4207-4282; Gokel, G. W.; Mukhopadhyay, A. Chem. Soc. Rev. 2001, 30, 274-286; Atwood, J. L.; Barbour, L. J.; Hardie, M. J.; Raston, C. L. Coord. Chem. Rev. 2001, 222, 3-32; Dixon, I. M.; Collin, J.P.; Sauvage, J.-P.; Flamigni, L.; Encinaa, S.; Barigelletti, F. Chem. Soc. Rev. 2000, 29, 385-391.

[2] Sessler, J. L.; Gale, P. A.; Cho, W. S. Anion Receptor Chemistry; Royal Society of Chemistry: Cambridge, U.K., 2006; Bianchi, A.; Bowman-James, K.; Garcia-España E. Supramolecular chemistry of anions; Wiley-VCH: New York, 1996.

[3] Misra, R.; Chandrashekar, T. K. Acc. Chem. Res. 2008, 41 , 265-279; Lankshear, M. D.; Beer, P. D. Acc. Chem. Res. 2007, 40, 657-668; Filby, M. H.; Steed, J. W. Coord. Chem. Rev. 2006, 250, 3200-3218; García-España, E.; Díaz, P.; Llinares, J. M.; Bianchi, A. Coord. Chem. Rev. 2006, 250, 2952-2986; Davis, A. P. Coord. Chem. Rev. 2006, 250, 2939 2951; Anzenbacher, P.; Nishiyabu, R.; Palacios, M. A. Coord. Chem. Rev. 2006, 250, 2929-2938; Gale, P. A. Acc. Chem. Res. 2006, 39, 465-475; Amendola, V.; Esteban-Gómez, D.; Fabbrizzi, L.; Licchelli, M. Acc. Chem. Res. 2006, 39, 343353; Chandrashekar, T. K.; Venkatraman, S. Acc. Chem. Res. 2003, 36, 676-691; Sessler, J. L.; Davis, J. M. Acc. Chem. Res. 2001, 34, 989-997.

[4] (a) Metrangolo, P.; Meyer, F.; Pilati, T.; Resnati, G.; Terraneo G. Chem. Commun. 2008, 1635-1637; (b) Casnati, A.; Liantonio, R.; Metrangolo, P.; Resnati, G.; Ungaro, R.; Ugozzoli, F. Angew. Chem. Int. Ed. 2006, 45, 1915-1918; (c)
Liantonio, R.; Metrangolo, P.; Meyer, F.; Pilati, T.; Navarrini, W.; Resnati, G. Chem. Commun. 2006, 1819-1821; (d) Gimeno, N.; Vilar, R. Coord. Chem. Rev. 2006, 250, 31613189; (e) Gale, P. A.; Quesada, R. Coord. Chem. Rev. 2006. 250, 3219-3244; (f) Lankshear, M. D.; Beer, P. D. Coord. Chem. Rev. 2006, 250, 3142-3160; (g) Wichmann, K.; Antonioli, B.; Söhnel, T.; Wenzel, M.; Gloe, K.; Gloe, K.; Price, J. R.; Lindoy, L. F.; Blake, A. J.; Schröder, M. Coord. Chem. Rev. 2006, 250, 2987-3003; (h) Liantonio, R.; Metrangolo, P.; Pilati, T.; Resnati, G. Cryst. Growth \& Des. 2003, 3, 355-361; (i) Farina, A.; Meille, S. V.; Messina, M. T.; Metrangolo, P.; Resnati, G. Angew. Chem. Int. Ed. 1999, $38,2433-2436$.

[5] Metrangolo, P.; Meyer, F.; Pilati, T.; Resnati, G.; Terraneo, G. Angew. Chem. Int. Ed. 2008, 47, 6114-6127; Metrangolo, P.; Resnati, G.; Pilati, T.; Liantonio, R.; Meyer, F. J. Polymer Chem. A, 2007, 45, 1-15; Metrangolo, P.; Pilati, T.; Resnati, G. CrystEngComm, 2006, 8, 946-947; Metrangolo, P; Neukirch, H.; Pilati, T.; Resnati, G. Acc. Chem. Res. 2005, 38, 386-395; Metrangolo, P.; Pilati, T.; Resnati, G.; Stevenazzi, A. Current Opinion Coll. Interface Sc. 2003, 8, 215-222; Metrangolo, P.; Resnati, G. Chem. Eur. J. 2001, 7, 25112519.

[6] Metrangolo, P.; Panzeri, W.; Recupero, F.; Resnati, G. J. Fluorine Chem. 2002, 114, 27-33; Messina, M. T.; Metrangolo, P.; Panzeri, W.; Ragg, E.; Resnati, G. Tetrahedron Lett. 1998, 39, 9069-9072.

[7] (a) Lindeman, S. V.; Hecht, J.; Kochi, J. K. J. Am. Chem. Soc. 2003, 125, 11597-11606; (b) Bock, H.; Holl, S. Z. Naturforsch., B: Chem. Sci. 2001, 56, 152-154; (c) Lohr, HG.; Engel, A.; Josel, H.-P.; Vogtle, F.; Schuh, W.; Puff, H. J. Org. Chem. 1984, 49, 1621-1627.

[8] (a) Gattuso, G.; Pappalardo, A.; Parisi, M. F.; Pisagatti, I.; Crea, F.; Liantonio, R.; Metrangolo, P.; Navarrini, W.; Resnati, G.; Pilati, T.; Pappalardo, S. Tetrahedron 2007, 63, 4951-4958; (b) Fox, B. D.; Liantonio, R.; Metrangolo, P.; Pilati, T.; Resnati, G. J. Fluorine Chem. 2004, 125, 271-281.

[9] (a) Gattuso, G.; Liantonio, R.; Metrangolo, P.; Meyer, F.; Resnati, G.; Pappalardo, A.; Parisi, M. F.; Pilati, T.; Pisagatti, I.; Resnati, G. Supramol. Chem. 2006, 18, 235-243; (b) Caronna, T.; Liantonio, R.; Logothetis, T. A.; Metrangolo, P.; Pilati, T.; Resnati, G. J. Am. Chem. Soc. 2004, 126, 45004501.

[10]Rosokha, S. V.; Neretin, I. S.; Rosokha, T. Y.; Hecht, J.; Kochi J. K. Heteroat. Chem. 2006 17, 449-459; Logothetis, T. A.; Meyer, F.; Metrangolo, P.; Pilati, T.; Resnati, G. New. J. Chem. 2004, 28, 760-763; Yamamoto, H. M.; Maeda, R.; Yamaura, J.-I.; Kato, R. J. Mater. Chem. 2001, 11, 1034 1041.

[11]Nakamoto, T.; Wang, Q.; Miyazaki, Y.; Sorai, M. Polyhedron 2002, 21, 1299-1304.

[12] Bowman-James, K. Acc. Chem. Res. 2005, 38, 671-678.

[13] Gutsche, C. D. Calixarenes Revisited; Stoddart, J. F., Ed.; Monographs in Supramolecular Chemistry; The Royal Society of Chemistry: London, UK, 1998; Vicens, J.; Böhmer, V. Calixarenes: A Versatile Class of Macrocyclic Compounds; Eds.; Kluwer: Dordrecht, 1991; Gutsche, C. D. Calixarenes; Stoddart, J. F., Ed.; Monographs in Supramolecular Chemistry; The Royal Society of Chemistry: Cambridge, 1989; Vol. 1.

[14](a) Danil de Namor, A. F.; Zegarra-Fernandez, K. J. Phys. Chem. B 2007, 111, 7321-7330; (b) Barrett, G.; McKervey, M. A.; Malone, J. F.; Walker, A.; Arnaud-Neu, F.; Guerra, L.; 
Schwing-Weill, M.-J.; Gutsche, C. D.; Stewart, D. R. J. Chem. Soc., Perkin Trans. 2 1993, 1475-1479.

[15]Metrangolo, P.; Meyer, F.; Pilati, T.; Proserpio, D. M.; Resnati, G. Chem. Eur. J. 2007, 13, 5765-5772; Neukirch, H.; Guido, E.; Liantonio, R.; Metrangolo, P.; Pilati, T.; Resnati, G. Chem. Commun. 2005, 1534-1535; Metrangolo, P.; Pilati, T.; Resnati, G.; Stevenazzi, A. Chem. Commun. 2004, 1492 1493; Bertani, R.; Metrangolo, P.; Moiana, A.; Perez, E.; Pilati, T.; Resnati, G.; Rico-Lattes, I.; Sassi, A. Adv. Materials 2002, 14, 1197-1201.

[16] Arnaud-Neu, F.; Fanni, S.; Guerra, L.; McGregory, W.; Ziat, K.; Schwing-Weill, M.-J.; Barrett, G.; McKervey, M. A. Marrs, D.; Malone, J. F.; Walker, A.; Seward, E. M. J. Chem. Soc., Perkin Trans. 2 1995, 113-118.

[17]Upon addition of $\mathrm{NaI}$ ( 1 equiv.) to a $\mathrm{CDCl}_{3}(5.0 \mathrm{mM})$ of $\mathbf{1}$, the aromatic and ethereal $\mathrm{OCH}_{2}$ signals underwent a 0.11 and $0.10 \mathrm{ppm}$ downfield complexation induced shift, respectively. Similarly, positive ESI-MS analysis of a $10 \mathrm{mM}$ $\mathrm{CHCl}_{3} / \mathrm{CH}_{3} \mathrm{OH}$ solution of $\mathbf{1}: \mathrm{NaI}(1: 1)$ showed a peak at $\mathrm{m} / \mathrm{z}=$ 1263.7, consistent with the formation of a $[\mathbf{1} \cdot \mathrm{Na}]^{+}$complex.

[18]Bell, S. E. J.; Browne, J. K.; McKee, V.; McKervey, M. A. Malone, J. F.; O'Leary, M.; Walker, A. J. Org. Chem. 1998 $63,489-501$.

[19] $t$ and $g$ stand for trans and gauche, respectively.

[20]Smart, B. E. In Organofluorine Chemistry: Principles and Commercial Applications; Banks, R. E., Smart, B. E., Tatlow, J. C., Eds.; Plenum Press: New York, 1994; Dorset, D. L. Macromolecules 1990, 23, 894-901; Hildebrand, J.; Cochran, D. R. F. J. Am. Chem. Soc. 1949, 71, 22-25.

[21] Amati, M.; Lelj, F.; Liantonio, R.; Metrangolo, P.; Luzzati, S. Pilati, T.; Resnati, G. J. Fluorine Chem. 2004, 125, 629-640; Liantonio, R.; Metrangolo, P.; Pilati, T.; Resnati, G.; Stevenazzi, A. Cryst. Growth \& Des. 2003, 3, 799-803; Navarrini, W.; Messina, M. T.; Metrangolo, P.; Pilati, T.; Resnati, G. New J. Chem. 2000, 24, 777-780; Cardillo, P.; Corradi, E.; Lunghi, A.; Meille, S. V.; Messina, M. T.; Metrangolo, P.; Resnati, G. Tetrahedron 2000, 56, 55355550; Corradi, E.; Meille, S. V.; Messina, M. T.; Metrangolo, P.; Resnati, G. Tetrahedron Lett. 1999, 40, 7519-7523.

[22]Burla, M. C.; Camalli, M.; Carrozzini, B.; Cascarano, G. L.; Giacovazzo, C.; Polidori G.; Spagna, R. J. Appl. Cryst. 2003, $36,1103$.

[23] Sheldrick, G. M. SHELXTL 6; Bruker AXS Inc., Madison, Wisconsin, USA, 2001. 


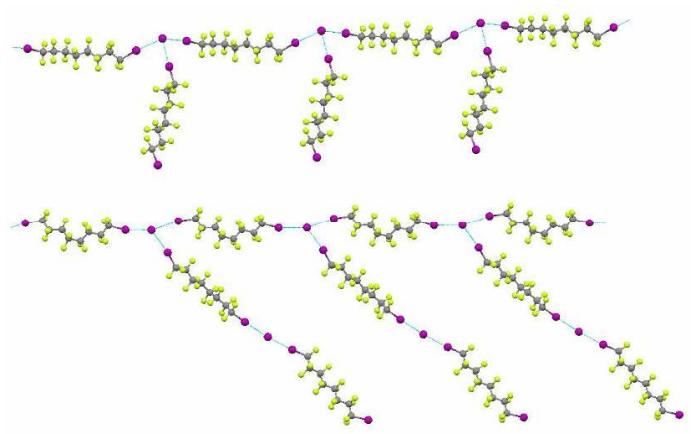



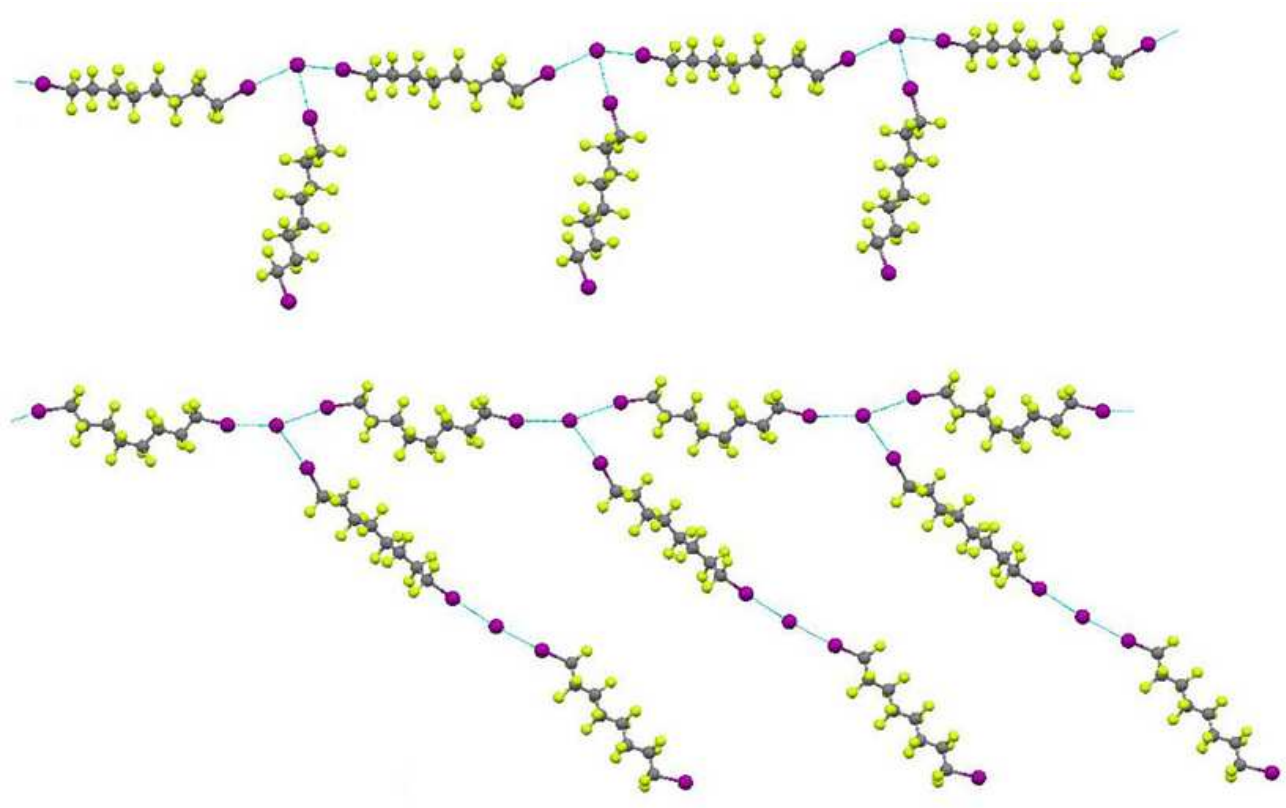

$35 \times 21 \mathrm{~mm}(600 \times 600 \mathrm{DPI})$ 


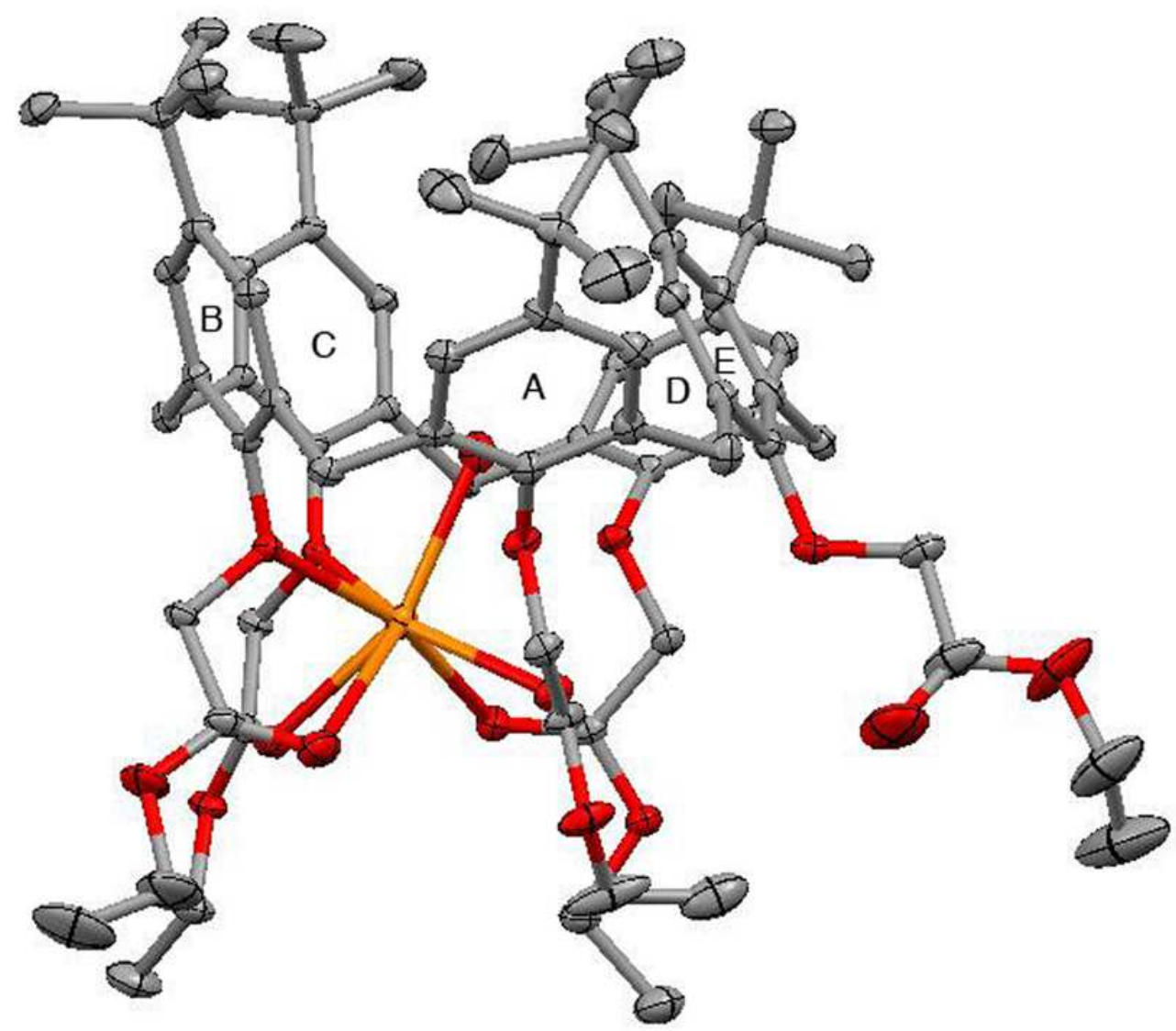

$35 \times 30 \mathrm{~mm}(600 \times 600 \mathrm{DPI})$

39

40

41

42

44

45

46

47

48

49

51

52

53

54

55

56

58

59

60 


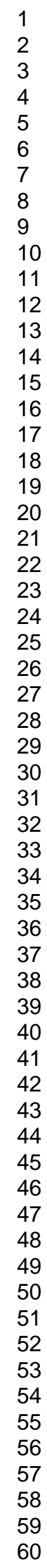

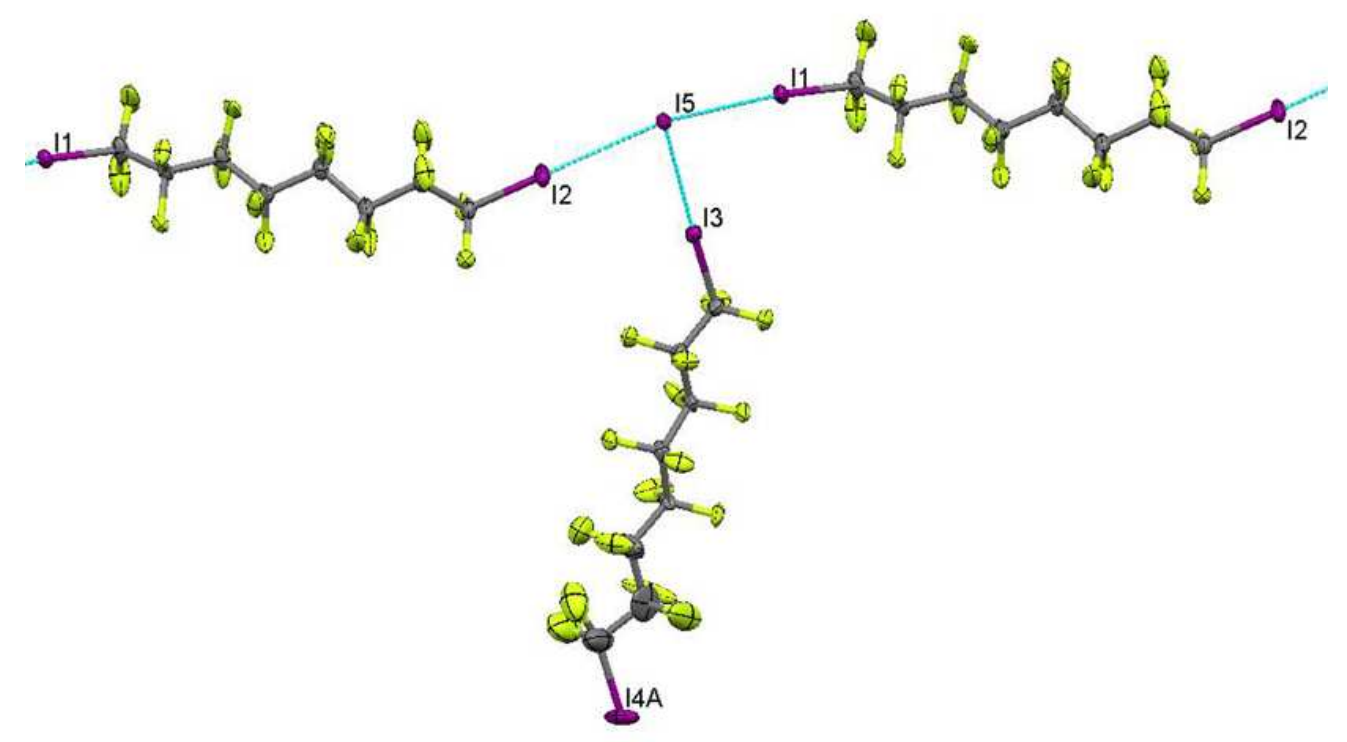

$35 \times 20 \mathrm{~mm}(600 \times 600$ DPI $)$ 


1
2
3
4
5
6
7
8
9
10
11
12
13
14
15
16
17
18
19
20
21
22
23
24
25
26
27
28
29
30
31
32
33
34
35
36
37
38
39
40
41
42
43
44
45
46
47
48
49
50
51
52
53
54
55
56
57
58
60
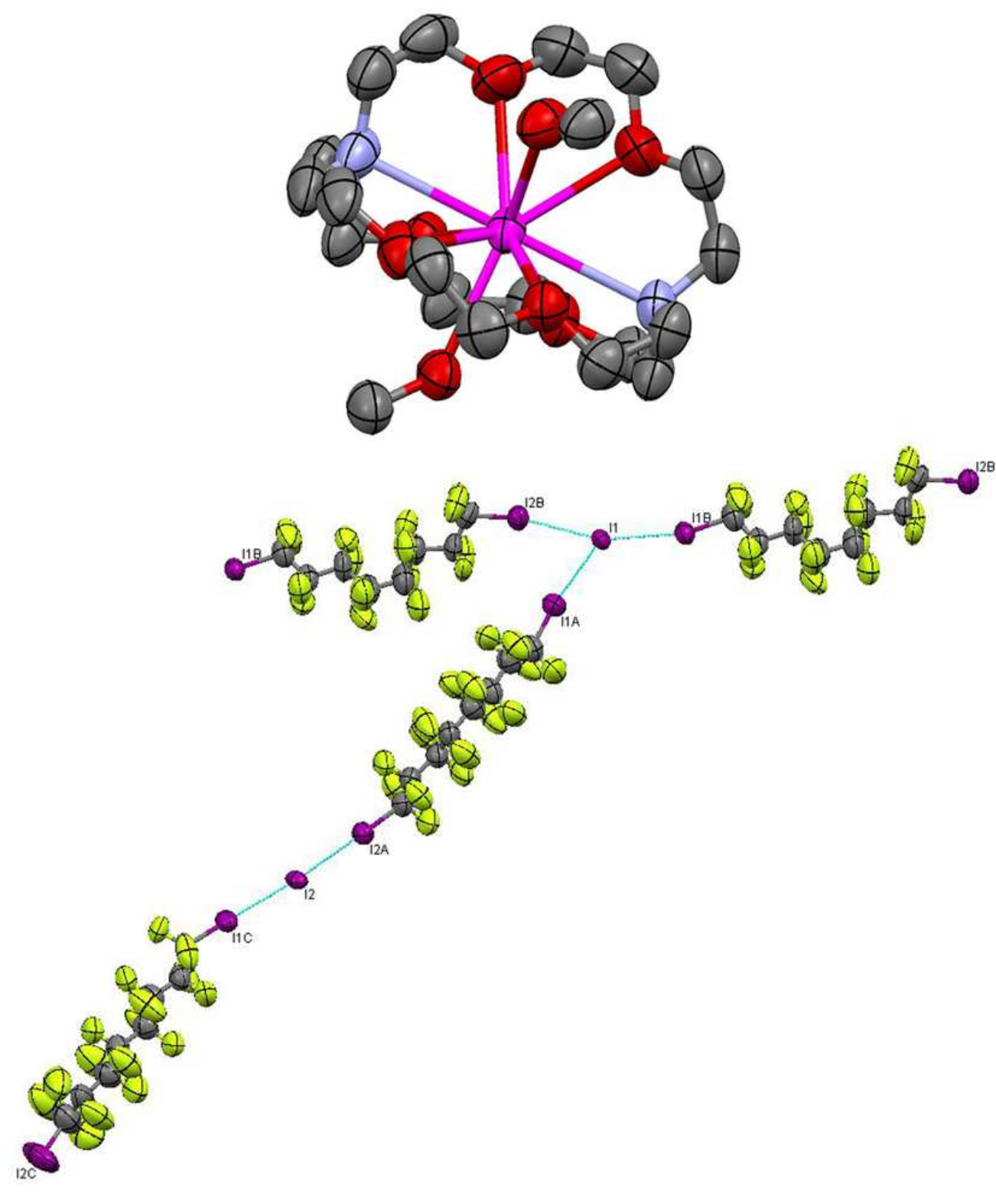

$35 \times 41 \mathrm{~mm}(600 \times 600 \mathrm{DPI})$ 
a)

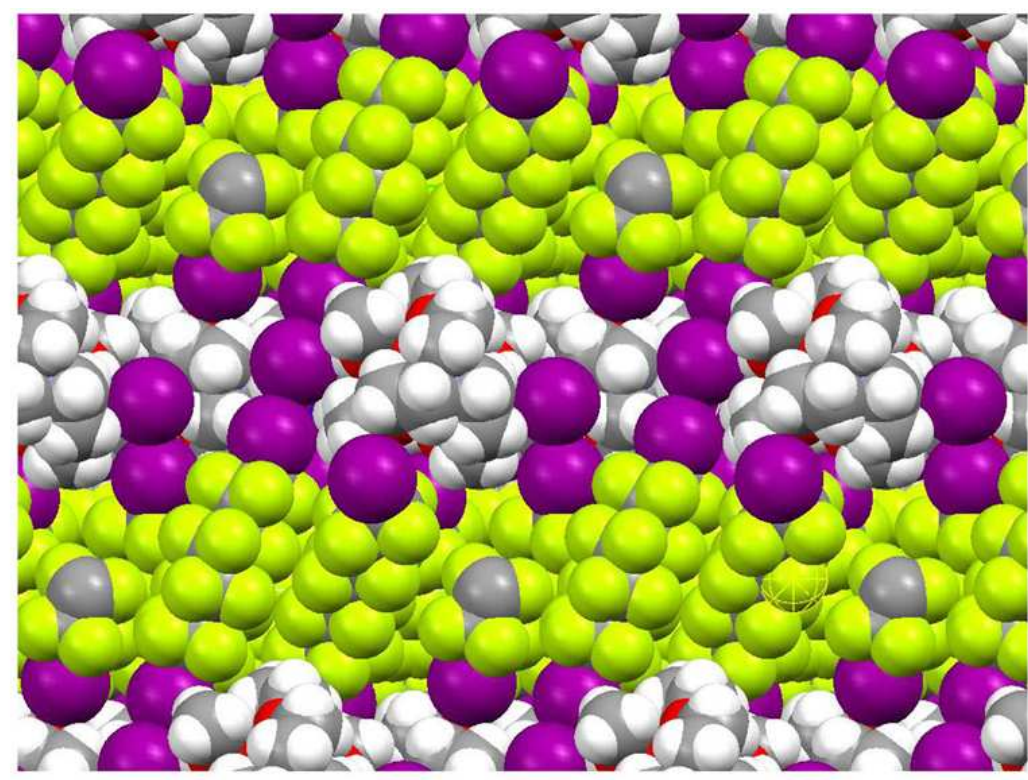

b)

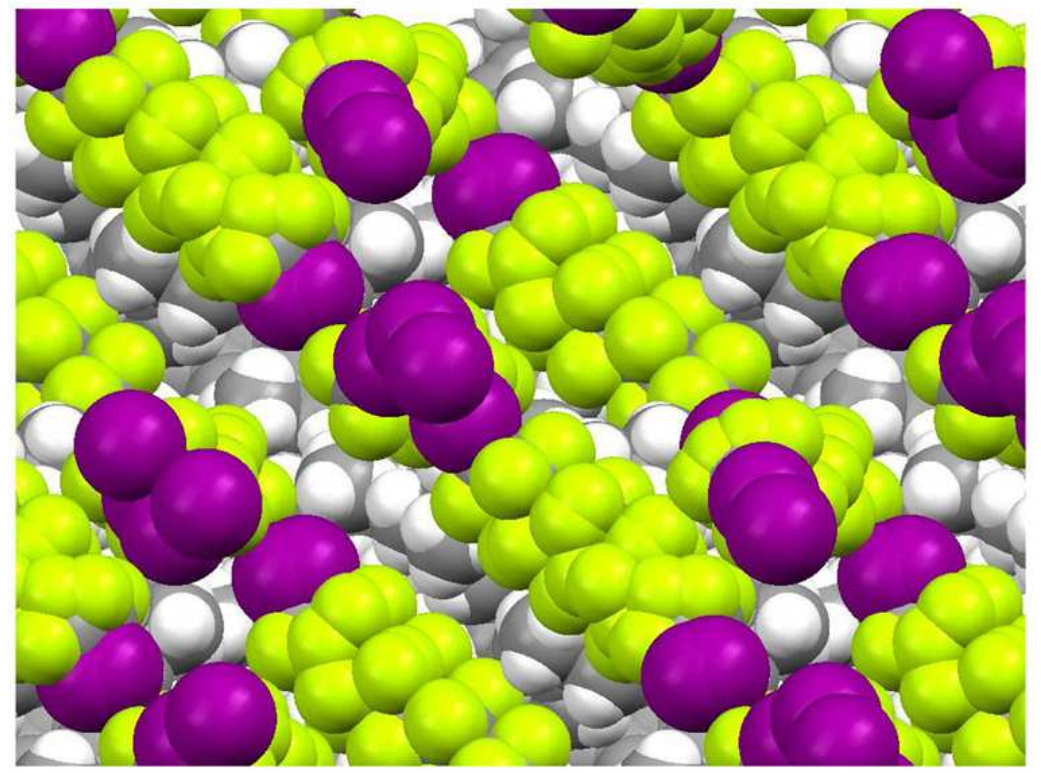

$35 \times 49 \mathrm{~mm}(600 \times 600 \mathrm{DPI})$ 


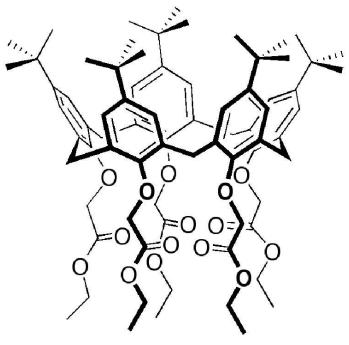

1 $\mathrm{Nal} / \mathrm{CH}_{3} \mathrm{OH}$
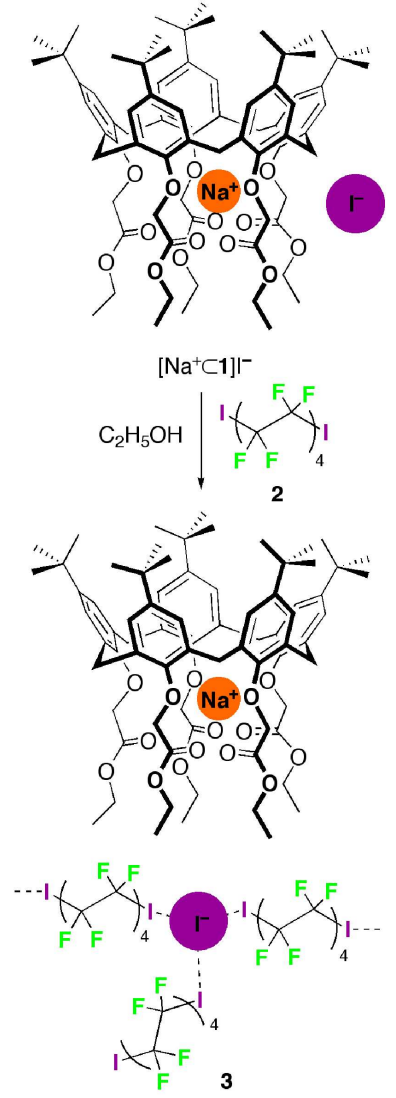

$35 \times 143 \mathrm{~mm}(600 \times 600 \mathrm{DPI})$

URL: http:/mc.manuscriptcentral.com/tandf/gsch Email: suprachem@mail.cm.utexas.edu 


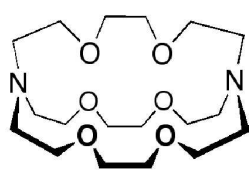

4 $\mathrm{Bal}_{2} / \mathrm{CH}_{3} \mathrm{OH}$
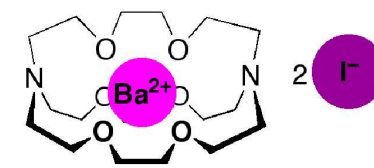

$\left[\mathrm{Ba}^{2+} \subset 4\right] 2 \mathrm{I}^{-}$
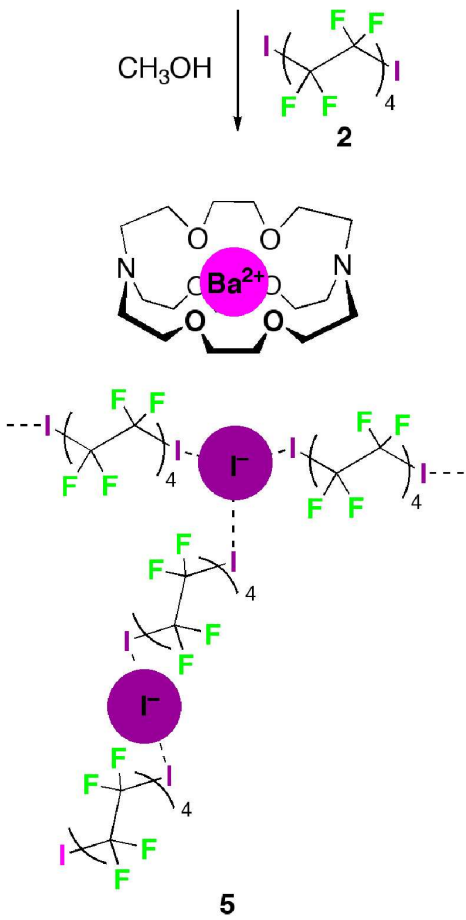

5

$35 \times 112 \mathrm{~mm}(600 \times 600 \mathrm{DPI})$ 


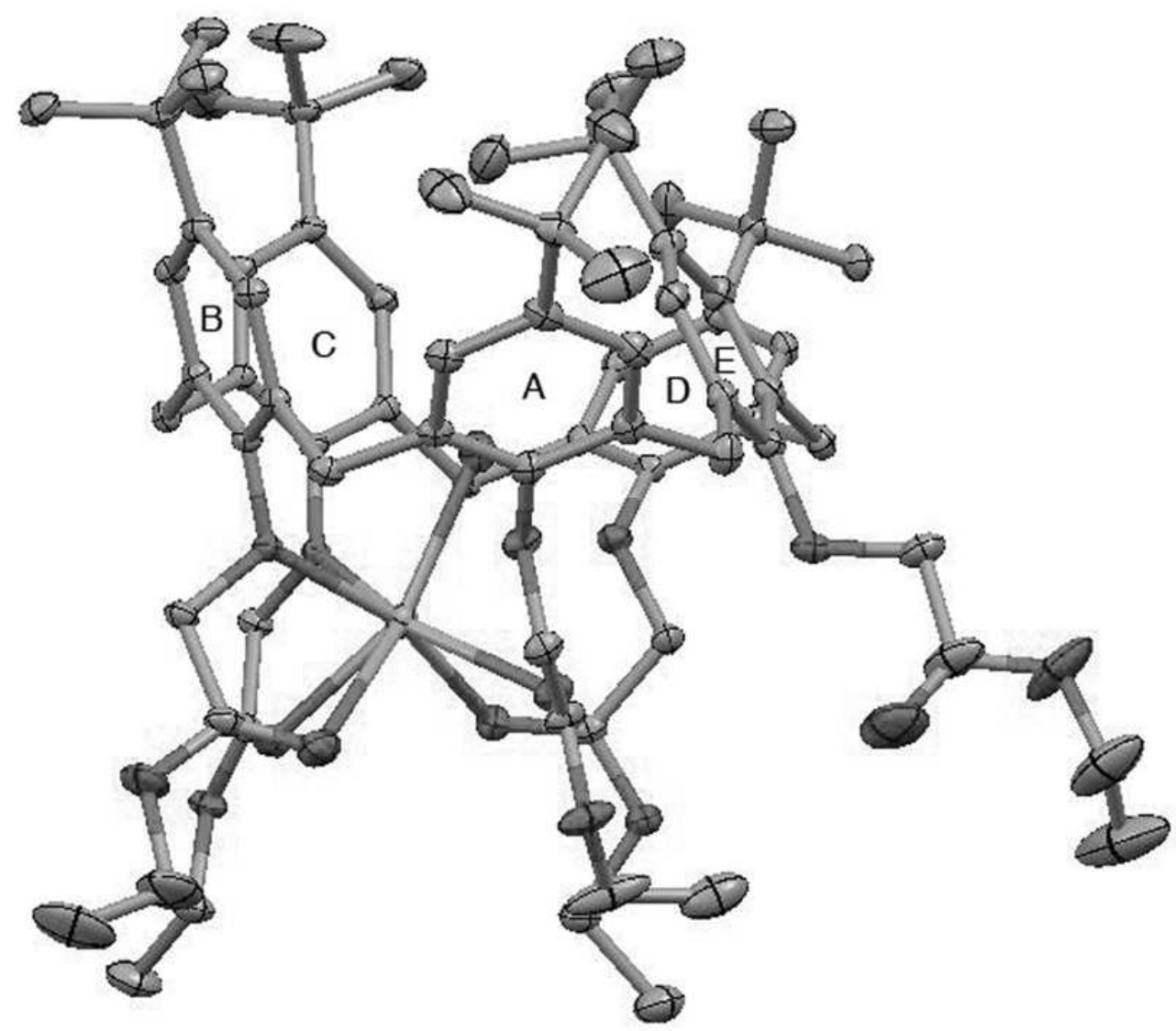

$35 \times 30 \mathrm{~mm}(600 \times 600 \mathrm{DPI})$

39

40

41

42

44

45

46

47

48

49

51

52

53

54

55

56

57

59

60 


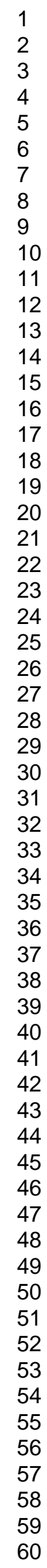

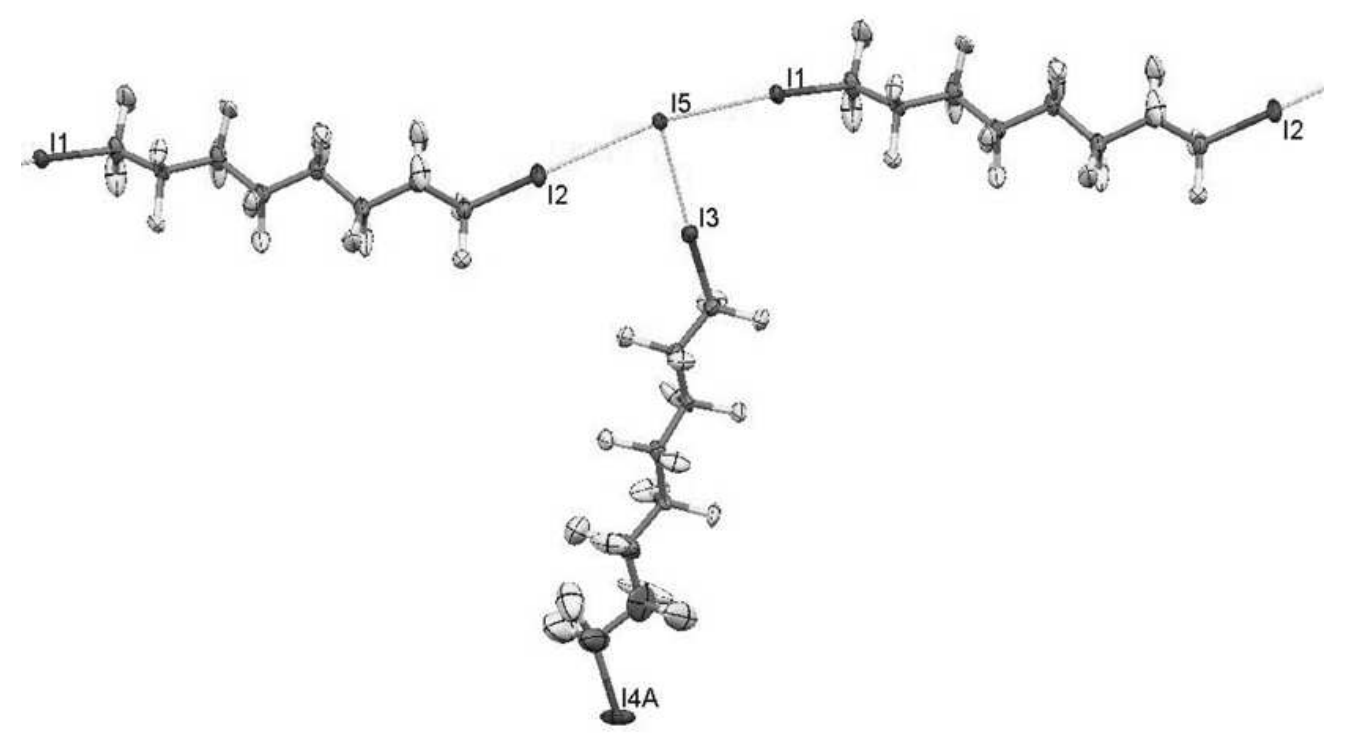

$35 \times 20 \mathrm{~mm}(600 \times 600$ DPI $)$ 


1
2
3
4
5
6
7
8
9
10
11
12
13
14
15
16
17
18
19
20
21
22
23
24
25
26
27
28
29
30
31
32
33
34
35
36
37
38
39
40
41
42
43
44
45
46
47
48
49
50
51
52
53
54
55
56
57
58
59
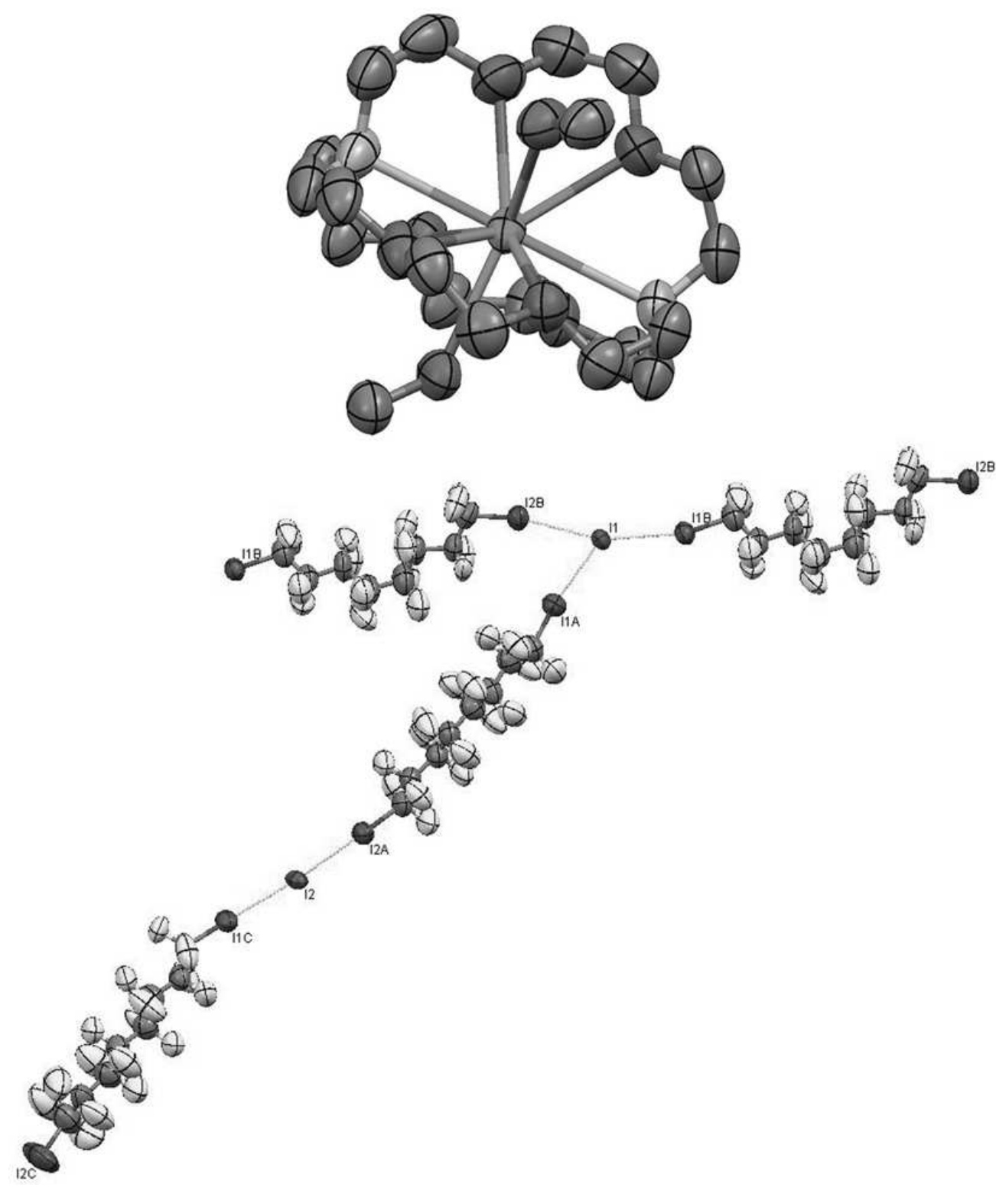

$35 \times 41 \mathrm{~mm}(600 \times 600$ DPI $)$

URL: http:/mc.manuscriptcentral.com/tandf/gsch Email: suprachem@mail.cm.utexas.edu 
a)

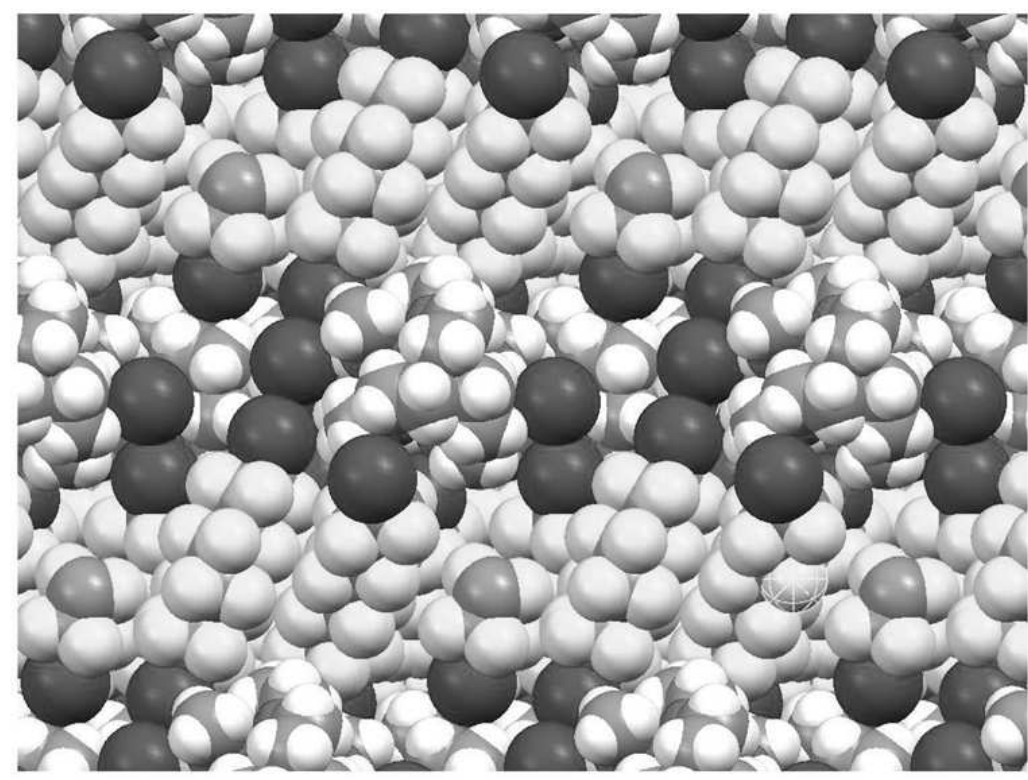

b)

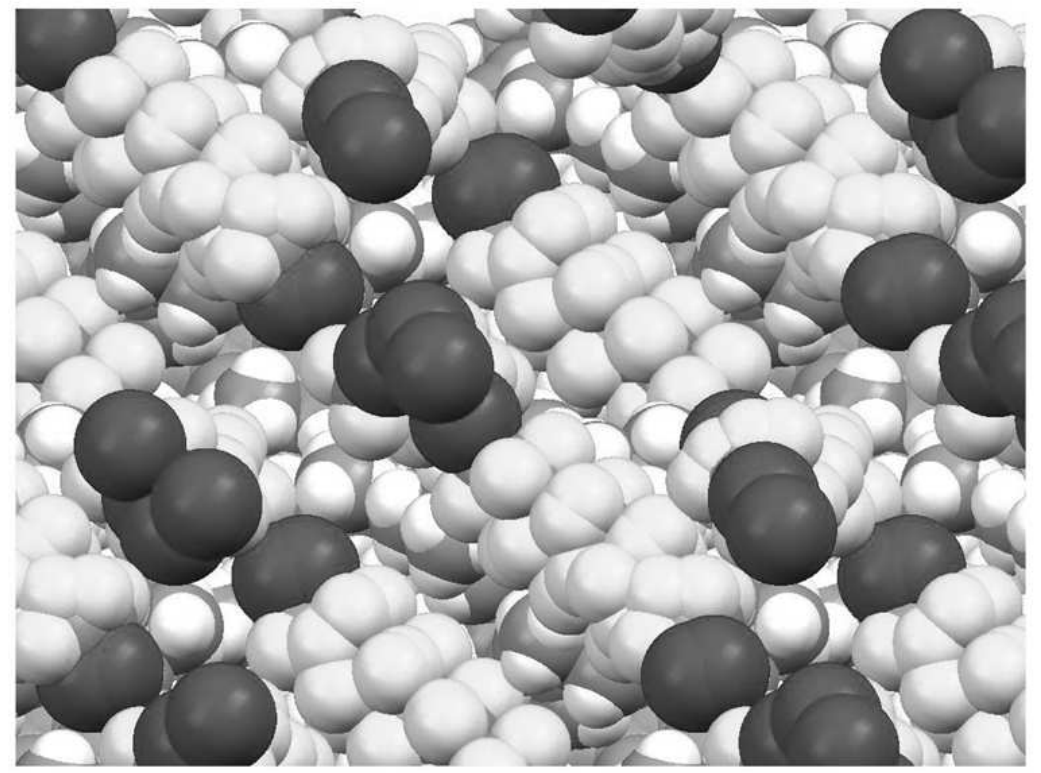

$35 \times 49 \mathrm{~mm}(600 \times 600 \mathrm{DPI})$ 


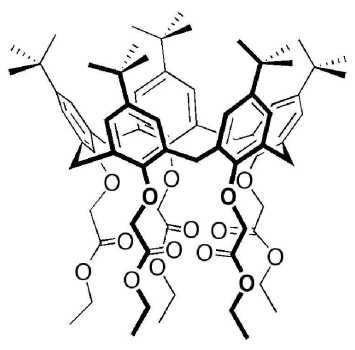

1

$\mathrm{Nal} / \mathrm{CH}_{3} \mathrm{OH}$

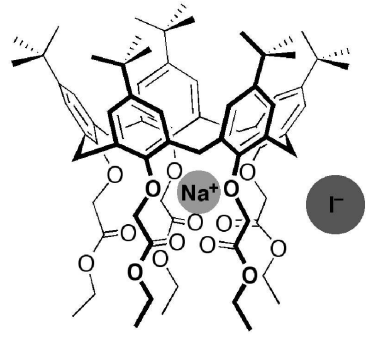

$\left[\mathrm{Na}^{+} \mathrm{C} 1\right]^{-}$
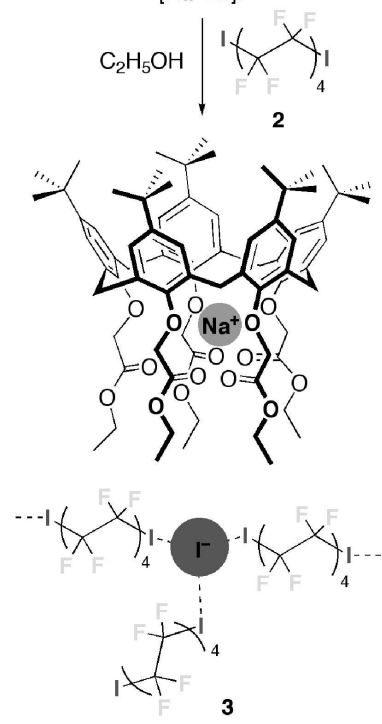

$35 \times 143 \mathrm{~mm}(600 \times 600 \mathrm{DPI})$

URL: http:/mc.manuscriptcentral.com/tandf/gsch Email: suprachem@mail.cm.utexas.edu 


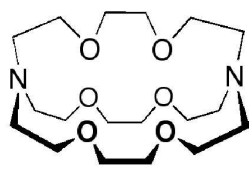

4 $\mathrm{Bal}_{2} / \mathrm{CH}_{3} \mathrm{OH}$

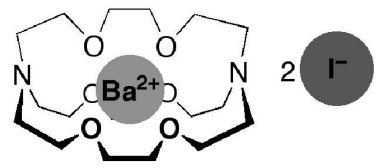

$\left[\mathrm{Ba}^{2+} \subset 4\right] 2 \mathrm{I}^{-}$
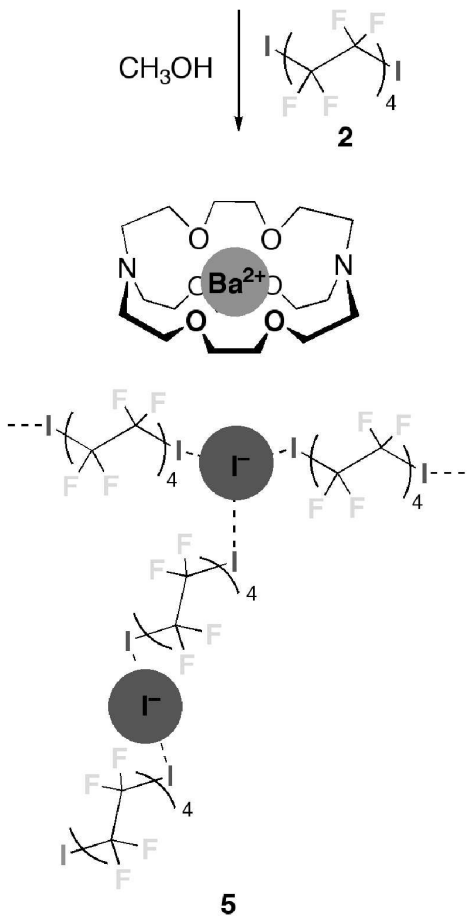

$35 \times 112 \mathrm{~mm}(600 \times 600 \mathrm{DPI})$

URL: http:/mc.manuscriptcentral.com/tandf/gsch Email: suprachem@mail.cm.utexas.edu 